\title{
POLA URUTAN FUNGSI KETERANGAN BERDASARKAN HUBUNGANNYA DENGAN PREDIKAT VERBA DALAM KALIMAT TUNGGAL DEKLARATIF BAHASA INDONESIA
}

\author{
Munariswati $^{1}$; Sumarlam ${ }^{2}$; Edi Subroto ${ }^{3}$ \\ ${ }^{1}$ Program Studi Linguistik, Pascasarjana, Universitas Sebelas Maret \\ ${ }^{2,3}$ Professor at Universitas Sebelas Maret, Surakarta, Indonesia \\ ${ }^{1}$ moenariswati@gmail.com; ${ }^{2}$ sumarlam@staff.uns.ac.id
}

\begin{abstract}
This study aims to explain the order of several adverbials phrase (fungsi Keterangan/ $K$ ) in indonesian simple declaratif sentence, and explain to any change the information if it's modified of pattern sequence. The study belongs to a descriptive qualitative study. The data sources of the study include both written and oral forms. The former are sourced from national print newspapers, while the latter are from the researcher herself regarding her linguistic intuition. The data comprise Indonesian simple declarative sentences in written expressions having several functions of $K$ which follow $P$. They were then analyzed using such methods as padan (identity) and distribusi (distribution). The analysis of data using a distribution methode with permutation and deletion technique. The analysis results of this study are 1) there are contained 10 types of $K$ an indonesian simple declarative sentence, 2) The $K$ combination often used in a simple sentence are location, time, events, manner, and instrumental, it depends on the role of the verb. 3 ) modification of the order of $K$ can change the information in the sentence, may becomes ambiguous, disconected or unclear information. 4) there is a preposition that is rigid with the verb, for example 'di' preposition can show a locative means on the verb 'existance or displacement' role.
\end{abstract}

Keywords: adverbials phrase (fungsi Keterangan), locative, temporal, comitative, methodical, and verb

\section{PENDAHULUAN}

Fungsi Keterangan (K) merupakan konstituen dalam kalimat yang sifatnya bukan inti atau manasuka penggunaanya. Namun K dibutuhkan dalam kalimat deklaratif khususnya dalam penyajian sebuah inforsmasi yang utuh. $\mathrm{K}$ dalam kalimat dapat disebut konstituen periferal, yang berarti sesuatu tambahan demi lengkapnya informasi di dalam klausa (Verhaar, 2001:166).

Keberadaan fungsi periferal yaitu $\mathrm{K}$ dalam kalimat deklaratif dapat memberikan tambahan wawasan yang akurat dari sebuah inti klausa. Dari segi semantis fungsi periferal yang melibatkan frasa preposisi juga merupakan satuan kebahasaan atau konstituen yang dapat dijadikan jawaban atas pertanyaan yang menggunakan kata tanya 
kapan (when), dimana (where), bagaimana (how), dan mengapa (why) atau bercerita tentang situasi yang diungkapkan di dalam kalimat (Aarts, 1997:74). Begitu pentingnya konstituen tambahan dalam menyajikan sebuah berita, maka perlu diselidiki pola urutan $\mathrm{K}$ yang runtut berdasarkan hubungan kemaknaan dengan konstituen lain dalam hal ini dengan verba predikat. Ini bertujuan untuk menghindari penyampaian informasi yang terputus, ambigu ataupun tidak efektif. Adapun letak $\mathrm{K}$ dalam kalimat yang berfungsi sebagai periferal dapat ditulis skema berikut .

$\begin{array}{lll}\mathbf{S ~ P} \mathrm{K}_{1} \mathrm{~K}_{2} \mathrm{~K}_{3} \ldots \mathrm{K}_{\max } & \longrightarrow & \mathrm{KK} \text { secara langsung } \\ \mathbf{S ~ P}(\mathrm{O} / \mathrm{Pl}) \mathrm{K}_{1} \mathrm{~K}_{2} \mathrm{~K}_{3} \ldots \mathrm{K}_{\max } & \rightarrow & \text { KK tidak langsung } \\ \mathrm{K}_{1} \mathrm{~K}_{2}(\mathbf{S}) \mathbf{P ~ K}_{3} \mathrm{~K}_{4} \mathrm{KK} & \longrightarrow & \text { tak beraturan }\end{array}$

Berdasarkan tipologi bahasa SVO/ SPO, K yang bersifat netral sebagai periferal dalam kalimat terletak mengikuti P. Maka, penelitian ini dibatasi pada K yang letaknya mengikuti P (sebelah kanan P) dalam kalimat, baik secara langsung pada verba intransitif ataupun tidak langsung (transitif). Adapun pengkajian pola urutan $\mathrm{K}$ ini bukan pola urutan yang berkaitan dengan bentuk-bentuk kategorial yang membentuk FAdv seperti yang telah diulas oleh peneliti sebelumnya yaitu Sudaryanto (1979). Namun pola urutan yang berkaitan dengan makna semantis $\mathrm{K}$ satu dengan $\mathrm{K}$ lain jika disusun seri yang berada di sebelah kanan P dalam kalimat deklaratif atau dapat pula disebut urutan tematik hierarki. Misalnya:

(1) Ibu pergi ke Jakarta dengan ayah sejak tadi malam.

K tempat Kpenyerta K waktu

Kalimat (1) memiliki $3 \mathrm{~K}$ yaitu ke Jakarta, dengan ayah, sejak tadi malam. Ketiganya mempunyai peran semantis yang berbeda yaitu lokatif, komitatif, dan temporal. Untuk mengetahui pola urutan peran semantis KK agar mendapatkan informasi yang tidak terputus dan linear dari kalimat tersebut, maka perlu penyelidikan mendalam. Salah satu teknik dalam menentukan pola urutan yaitu dengan permutasi seperti berikut.

(1-a) Ibu pergi ke Jakarta sejak tadi malam dengan ayah.

(1-b)? Ibu pergi sejak tadi malam ke Jakarta dengan ayah.

(1-c)? Ibu pergi sejak tadi malam dengan ayah ke Jakarta.

(1-d)? Ibu pergi dengan ayah sejak tadi malam ke Jakarta.

(1-e) Ibu pergi dengan ayah ke Jakarta sejak tadi malam. 
Bentuk permutasi (1-a)-(1-e) memiliki informasi yang dapat diterima, namun memiliki topikalisasi/ fokus yang berbeda, selain itu kadar koherensi tematiknya juga berbeda, sehingga pola urutan $\mathrm{K}$ memiliki tingkat ketegaran yang tidak sama dalam memberikan informasi. Kalimat (1), (1-a), dan (1-e) dapat diterima informasinya secara baik. Ketiga kalimat tersebut memiliki pola urutan $\mathrm{K}$ bermakna lokatif-komitatif atau sebaliknya jika disandingkan setelah $\mathrm{P}$ 'pergi' memiliki ketegaran informasi yang baik. Hal ini dapat dikatakan bahwa ketegaran letak $\mathrm{K}$ dapat dipengaruhi dari peran predikatnya. Kalimat (1b), (1c) dan (1d) informasi dapat diterima. Namun terdapat keterputusan informasi peran predikat dan bersifat informal. Berdasarkan contoh tersebut, maka $\mathrm{K}$ tempat dapat dikatakan menempati hierarki tertinggi dalam menentukan koherensi informasi daripada jenis $\mathrm{K}$ lain dengan $\mathrm{P}$ yang bermakna 'perpindahan/pergerakan'. Hal itu dapat dilihat dari peran V yaitu V pergi secara lingual menuntut adanya "tempat yang dituju" maka dalam penulisan urutan yang didahulukan lebih tepat dengan pemilihan $\mathrm{K}$ tempat terlebih dahulu dari pada yang lain. Selain itu, lingkup semantis $\mathrm{K}$ tempat ataupun waktumdapat mencakup keseluruhan kalimat daripada $\mathrm{K}$ yang mempunyai sifat semantis lain.

Adapun penyelidikan lebih lanjut dapat ditentukan dengan teknik-teknik lain yang tercantum pada metode penelitian. Seperti halnya Bresnan dan Moshi (1988), menentukan peran tematik hierarki pada penambahan argumen di bawah agen. Tematik hierarkhi adalah urutan peran tematik dari yang tertinggi dan yang paling rendah. Dalam heirarkhi tersebut agen menduduki peran tertinggi diikuti peran-peran berikutnya yang rankingnya lebih rendah, seperti beneficiery/maleficiary, ricipient, expiriencer, instrumental, patient and theme, location, dan motive. Secara skematis ditulis $\mathrm{Ag}>$ ben/mal $>$ recip/exp $>$ ins $>$ pt/th>loc $>$ mot (Bresnan dan Moshi, 1988:5).

Penelitian pola urutan yang berkaitan tematik hierarki, telah dilakukan dalam bahasa Jerman yaitu pola urutan frasa preposisi (FP) yang menduduki K dilihat dari peran semantisnya oleh Schwikert (2005). Dengan tipologi bahasa SOV, diterangkan pola urutan beberapa FP yang disusun secara seri di tengah kalimat 'Mittelfeld' (sebelah kanan dari finite V) yang dapat ditentukan hierarki tematiknya. Pola urutan FP dalam bahasa Jerman dapat disusun secara hierarki yaitu evidential > temporal > locative > comitative > benefactive > reason > source > goal > malefactive > instrumental / 
means /path > matter > manner. Sebagai contoh kalimat bahasa Jerman yang menerapkan hierarki tersebut adalah.

(2) Ich habe am Dienstag in Venedig geschlafen.

I have on Tuesday in Venice sleep.

K waktu K tempat

"I slept in Venice on Tuesday."

"Saya tidur di Venice pada hari Selasa."

(3) Ich habe an mindestens einem Tag für jeden Chef gearbeitet.

I have on at_least one day for each boss work.

\section{K waktu K Benefaktif}

"I have worked for each boss on at least one day."

"Saya telah bekerja untuk bos selama satu hari."

Kalimat (2-3) memenuhi tematik hierarki yang ditulis oleh Schwikert. Yaitu jika terdapat 2 FP antara $\mathrm{K}$ waktu dan tempat, maka $\mathrm{K}$ waktu > lok (kalimat 2), dan jika K waktu dan benefaktif maka K waktu> benefaktif (kalimat 3). Selain FP, pola urutan yang didasarkan peran semantis dalam bahasa Jerman juga terdapat pada penentuan urutan letak $\mathrm{K}$ dalam kalimat yang dikenal dengan kaidah tekamolo yaitu kaidah penulisan urutan K yang wajib. Artinya Jika sebuah kalimat mempunyai beberapa K, maka keterangan-keterangan itu terpola yang dimulai dari keterangan temporal, keterangan kausal, keterangan modal dan keterangan lokatif (Griesbach dalam Parera, 2009:19).

Penelitian ini memadukan $\mathrm{K}$ yang telah ada, kemudian didistribusikan dalam kalimat dengan batasan minimal dua $\mathrm{K}$ setiap kalimatnya. Pendistribusian tersebut bertujuan untuk mencari tematik hierarki pola urutan beberapa $\mathrm{K}$ yang terdapat dalam kalimat deklaratif jika digunakan dalam waktu bersamaan, sehingga diperoleh kaidah pola urutannya. Penentuan pola hierarkial ini semata-mata bertujuan mengurutkan informasi sehingga membantu pembaca dalam penelusuran tempat/ kejadian atau keterangan lain. Selaian itu keruntutan penyusunan K secara benar dapat memberikan beberapa manfaat, diantaranya adalah memberikan kemudahan penulusuran informasi pada publik pembaca, memberikan edukasi informasi pada publik pembaca, dapat memberikan aspek ketercukupan informasi dan keefektifan kalimat. 


\section{TEORI DAN METODOLOGI}

\section{Fungsi Sintaksis dalam Kalimat}

Fungsi sintaksis berkaitan dengan konstituen "formal" yang tidak terikat pada unsur semantis tertentu (asalkan menjadi salah satu peserta pada verba), tidak juga terikat dengan unsur kategorial tertentu (asalkan nomina, bermarkah dengan preposisi atau bentuk kasus tanpa pemarkahan tersebut) (Verhaar (2001:167).

Fungsi sintaksis di dalamnya terdiri dari beberapa konstituen yang disebut dengan subjek $(S)$, predikat $(P)$, objek $(O)$, pelengkap/ komplemen (pel/kom), dan keterangan $(K)$. Secara umum fungsi tersebut dapat dibagankan seperti berikut.

\begin{tabular}{|c|c|c|c|}
\hline S & P & O/Pel & K \\
\hline
\end{tabular}

Dari bagan tersebut secara formal fungsi $\mathrm{S}$ dan $\mathrm{P}$ harus selalu ada dalam setiap klausa karena keduanya saling "berkaitan". Dalam hal ini dapat dikatakan bahwa S adalah bagian klausa yang menandai apa yang dinyatakan oleh pembicaraan, sedangkan $\mathrm{P}$ adalah bagian klausa yang menandai apa yang dinyatakan oleh pembicaraan mengenai S (Kridalaksana, 2002).

Subjek (S) merupakan konstituen kalimat yang memiliki ciri-ciri: pada umumnya berupa $\mathrm{N}$, terletak di sebelah kiri predikat, dan menjadi objek akibat pemasifan kalimat (Alwi, 2003). Sedangkan menurut Verhaar (2001) S merupakan konstituen yang berelasi dengan $\mathrm{V}$, maksutnya adalah $\mathrm{S}$ dapat dimengerti hanya sebagai "S dari V" (yang di tempat P).

Predikat merupakan konstituen pokok yang disertai konstituen subjek di sebelah kiri, dan jika ada, konstituen objek, pelengkap dan/ atau keterangan yang berada di sebelah kanan (Alwi, Dkk, 2003:326). Kemudian Ramlan (2001) mengatakan bahwa predikat merupakan unsur klausa yang selalu ada dan merupakan pusat klausa karena memiliki hubungan dengan unsur-unsur lainnya, yaitu dengan $\mathrm{S}, \mathrm{O}$, dan $\mathrm{K}$.

Objek (O) merupakan konstituen kalimat yang kehadirannya dituntut oleh predikat yang berupa verba transitif pada kalimat aktif, letaknya selalu langsung setelah predikatnya, dan menjadi subjek akibat pemasifan kalimat (Alwi, 2003).

Pelengkap merupakan fungsi sintaktik yang adanya karena watak transitif verba pengisi P bukan berafiks $m e(N)$ - dengan pengisi yang tak dapat mengisi subjek, karena 
tidak ada parafrasanya. Kemudian menurut Alwi, dkk (2003) Pl merupakan konstituen yang memiliki ciri-ciri: bersifat wajib hadir untuk melengkapi suatu perbuatan, terletak di belakang predikat jika tidak ada objek dan di belakang objek kalau unsur ini ada, dan tak dapat menjadi subjek akibat pemasifan kalimat. Kedua definisi tersebut saling melengkapi pengertian Pl. Namun pada ciri Pl yang terletak di belakang P, maka perlu dijelaskan persamaan dan perbedaan dengan $\mathrm{O}$ yang sifatnya juga sama berada setelah P.

Persamaan dan perbedaan antara O dan Pl menurut Alwi, dkk (2003:329) dapat dibuat tabel berikut.

Tabel 1. Persamaan dan Perbedaan antara O dan PL

\begin{tabular}{|l|l|l|}
\hline No & \multicolumn{1}{|c|}{ Objek } & \multicolumn{1}{|c|}{ Pelengkap } \\
\hline 1 & Berwujud FN atau klausa & $\begin{array}{l}\text { Berwujud FN, FV, FAdj, FPrep, atau } \\
\text { klausa }\end{array}$ \\
\hline 2 & $\begin{array}{l}\text { Berada langsung di belakang } \\
\text { predikat }\end{array}$ & $\begin{array}{l}\text { Berada langsung dibelakang P jika tidak } \\
\text { ada O, dan di belakang O jika unsur itu } \\
\text { hadir. }\end{array}$ \\
\hline 3 & $\begin{array}{l}\text { Menjadi subjek akibat pemasifan } \\
\text { kalimat }\end{array}$ & $\begin{array}{l}\text { Tak dapat menjadi S akibat permasifan } \\
\text { kalimat }\end{array}$ \\
\hline 4 & $\begin{array}{l}\text { Dapat diganti dengan pronomina - } \\
\text { nya }\end{array}$ & $\begin{array}{l}\text { Tidak dapat diganti dengan-nya kecuali } \\
\text { dalam kombinasi preposisi selain di, ke, } \\
\text { dari, dan akan }\end{array}$ \\
\hline
\end{tabular}

Keterangan (K) merupakan bagian luar inti klausa. K merupakan konstituen "periferal". Maksudnya adalah konstituen yang berfungsi sebagai tambahan demi lengkapnya sebuah informasi di dalam klausa (Verhaar, 2001). Hal itu juga mempengaruhi letak posisi $\mathrm{K}$ di dalam klausa yaitu bersifat fleksibel, artinya dapat berada pada awal klausa maupun pada akhir klausa. Seperti ciri-ciri K menurut (Alwi, dkk, 2003) adalah berupa frasa nominal, frasa preposisional, atau frasa adverbial, paling mudah berpindah letak, dan kehadirannya dalam kalimat bersifat manasuka.

Adapun perbedaan Pl dengan $\mathrm{K}$ adalah sifat kehadiran konstituen dalam kalimat. Pl bersifat wajib hadir, sedangkan K tidak. Perbedaan kedua ialah mobilitas letak fungsi tersebut. Posisi Pl bersifat tegar dengan $\mathrm{P}$, sedangkan posisi $\mathrm{K}$ bersifat labil (dapat berpindah-pindah posisi) kecuali antara P-O/Pl (Alwi dkk, 2003). Pl yang berbentuk frasa prep dapat berpindah posisi sebelum subjek (Sukesti, 2002). Namun posisi P1 tersebut hanya dijumpai dalam bahasa lisan karena Pl itu membutuhkan intonasi tertentu 
(intonasi topik-komen \# $23 / 232$ \#), sedangkan dalam bahasa tulis hal tersebut sangat jarang ditemukan.

\section{Metode Penelitian}

Metode yang digunakan adalah metode deskripsi, karena penelitian ini lebih mementingkan deskripsi proses terhadap mengapa dan bagaimana sesuatu dapat terjadi dan mengarah pada pemahaman makna (Sutopo, 2006:138).

Metode yang digunakan dalam menganalisis data penelitian ini dibagi menjadi dua yaitu metode padan dan metode distribusional. Metode Padan adalah metode yang digunakan untuk mengkaji atau menentukan identitas satuan lingual tertentu dengan menggunakan alat penentu yang berada di luar bahasa, terlepas dari bahasa, dan tidak menjadi bagian bahasa yang bersangkutan (Subroto, 2007:59, Sudaryanto:1988a:2). Metode distribusional merupakan metode agih. Metode ini menggunakan alat penentu yaitu unsur bahasa itu sendiri.

\section{HASIL DAN PEMBAHASAN}

Peran semantis dalam menentukan jenis pengisi fungsi $\mathrm{K}$ dalam penelitian ini ditemukan 9 sifat Keterangan dan 10 jenis keterangan. Yaitu lokatif, temporal, acara, metodikal, instrumental, komitatif, final/goal, kausal, agentif, dan benefaktif.

Tabel2. Peran K dalam kalimat

\begin{tabular}{|l|l|l|}
\hline No & $\begin{array}{c}\text { K berdasarkan sifat hubungannya dengan } \\
\text { Verba Predikat }\end{array}$ & \multicolumn{1}{c|}{ Jenis Keterangan } \\
\hline 1 & Lokatif & tempat \\
\hline 2 & Temporal & waktu \\
\cline { 3 - 3 } & & acara \\
\hline 4 & Metodikal & cara \\
\hline 5 & Instrumental & alat \\
\hline 6 & Komitatif & penyerta \\
\hline 7 & Final/goal & tujuan \\
\hline 8 & Kausal & sebab \\
\hline 9 & Agentif & pelaku \\
\hline 10 & Benefaktif & penerima \\
\hline
\end{tabular}

Dalam penentuan pola urutan $\mathrm{K}$ tersebut, maka dibutuhkan beberapa kombinasi dari semua jenis tersebut. Pengkombinasian dibedakan menjadi 2 bentuk yaitu 2 kombinasi dan 3 kombinasi. 2 kombinasi terdapat 45 macam, sedangkan 3 kombinasi terdiri dari 120 macam. Namun pengkombinasian dalam makalah ini dibahas kombinasi K yang 
sering muncul atau digunakan dalam kalimat tunggal deklaratif. Kombinasi tersebut adalah:

\subsection{Lokatif - Temporal}

Kombinasi antara Lok- Temp (K tempat dan waktu) dalam kalimat dapat dikatakan sebagai $\mathrm{K}$ yang sering digunakan dan dijumpai dalam kalimat deklaratif. $\mathrm{K}$ ini dianggap penting kehadirannya untuk memenuhi informasi yang lengkap dalam sebuah berita. Adapun letak dalam kalimat $\mathrm{K}$ tempat dan waktu mempunyai tingkat kebebasan yang tinggi dari pada K yang lain (Schweikert, 2005:11). Hal ini dikarenakan sifat kedua $\mathrm{K}$ tersebut dapat memberikan keterangan yang mencakup keseluruhan kalimat. Dalam grammar bahasa Inggris, kemunculan K wkt dan tmpt dipilih sebagai susunan K yang ideal. Meskipun dalam sebuah kalimat biasa, keduanya dapat dipermutasi tanpa mengalami perubahan informasi seperti berikut.

(4) JK tiba di kompleks Istana Kepresidenan, Jalan Medan Merdeka $\mathrm{K}$ tmp

Utara , Jakarta, Senin (16/1) pukul 12.30 WIB.

K wkt

Untuk menguji pola urutan $\mathrm{K}$ antara tempat-waktu maka kalimat tersebut dipermutasikan yaitu diperoleh perubahan berikut.

(4a) JK tiba Senin (16/1) pukul 12.30 WIB di kompleks Istana Kepresidenan, Jalan Medan Merdeka Utara, Jakarta.

(4b) JK tiba (pada) Senin (16/1) pukul 12.30 WIB di kompleks Istana Kepresidenan, Jalan Medan Merdeka Utara, Jakarta.

Bentuk permutasi standar dari (4) adalah (4a). (4b) merupakan bentuk lengkap K dengan panambahan prep pada. Secara gramatikal, hasil permutasi standar tersebut dapat diterima informasinya. Namun dari segi semantis dan dari sifat distribusi paralel kalimat, ketika fungsi $\mathrm{P}$ diisi $\mathrm{V}$ berperan 'peralihan tempat atau arah', maka diprioritaskan K tempat yang pertama mengikuti fungsi P. Menurut Alwi dkk (2003), hal tersebut merupakan K wajib. Hal ini dapat dikatakan bahwa K tempat-waktu ( Lok> Temp). Selain data tersebut dapat dilihat pada data dengan $\mathrm{V}$ yang berperan sama halnya dengan data (8).

(5) Ia berangkat ke Bandung sejak kemarin

$\mathrm{S} \quad \mathrm{P}$ K tempat K waktu

(5a) ? Ia berangkat sejak kemarin ke Bandung

$$
\text { S P K wkt K tmpt }
$$


Perbandingan antara (5) dan (5a) untuk mendapatkan informasi secara paralel lebih diterima pada (5) dari pada (5a). K ke Bandung pada (5) mengikuti V 'berangkat' bersifat 'melengkapi' dan tindakan dari 'berangkat' menuntut adanya 'tempat yang dituju'. Namun tuntutan tersebut tidak bersifat wajib karena tidak mengganggu kegramatikalan. Kalimat 'saya berangkat' secara gramatikal dapat diterima namun secara semantik tidak lengkap dan tidak informatif. Untuk memenuhi kelengkapan tersebut disajikan dua $\mathrm{K}$ yang melibatkan $\mathrm{K}$ tempat dan waktu. Jika penambahan $\mathrm{K}$ waktu dengan pengubahan urutan pada (5a) informasi kalimat bersifat ambigu dan tidak linear. Hal tersebut dilihat dari V yang berperan 'peralihan'. K tempat memiliki relasi yang kuat dengan $\mathrm{V}$ daripada $\mathrm{K}$ waktu. Tingginya relasi $\mathrm{K}$ tempat terhadap $\mathrm{V}$ dapat menentukan pola urutan yang umum digunakan antara keduanya. Hal tersebut sering dijumpai pada $\mathrm{V}$ yang berperan peralihan/adanya gerak perpindahan atau lokatif.

Selain dengan cara melihat V-nya (topikalisasi V), penentuan prioritas pola urutan antara K tempat-waktu dengan cara pelesapan salah satu K-nya. Misalnya.

(4c) JK tiba di kompleks Istana Kpresidenan, Jalan Medan Merdeka Utara , Jakarta.

(4d) JK tiba (pada) Senin (16/1) pukul 12.30 WIB

(5b) Ia berangkat ke Bandung.

(5c) Ia berangkat besuk pagi.

Pelesapan K waktu pada (4c) masih bisa berterima secara gramatikal dan semantis. Namun pada (4d) secara semantis kurang lengkap yaitu membutuhkan K tempat untuk memenuhi peran dari V-nya dan atas pertanyaan "dimana JK tiba?". Kemudian pada (5b) dengan $\mathrm{K}$ ke Bandung dapat terpenuhi kebutuhan informasinya. Pada (5d) kelengkapan informasi masih kurang jika dalam wacana baku khususnya bersifat deklaratif, namun jika dalam wacana informal masih dapat diterima dalam mendapatkan informasi yang utuh dengan syarat pihak pembaca atau penutur mengetahui knowledge hal yang dibicarakan.

Selain itu, untuk menentukan urutan pola urutan K tempat-waktu dapat disimpulkan melalui frekuensi kemunculan dalam kalimat yang digunakan sebagai data (Walter, 2005). Hal ini juga sesuai dengan pendapat Kaswanti Purwo (1987) dalam artikelnya berjudul "pola urutan SV/VS dan Perubahan Sintaksis Bahasa Indonesia. Dalam makalah tersebut diungkapkan dalam menentukan pola urutan SV/VS menggunakan perhitungan frekuensi kemunculan antara SV dan VS. Begitu pula dengan pola urutan K 
yang diisi dari $\mathrm{K}$ tempat-waktu dapat dihitung dengan frekuensi kemunculannya di setiap penggunaan.

\subsection{Lokatif - acara/event}

Kalimat yang menggunakan $\mathrm{K}$ yang diisi dengan $\mathrm{K}$ tempat dan acara biasanya bersifat fleksibel. $\mathrm{K}$ tempat-acara dapat dipertukarkan tempatnya namun keduanya dapat dapat ditentukan pola urutan yang sering digunakan dalam suatu kalimat. Misalnya pada data berikut.

(6) Ibu mendapatkan hadiah dalam acara gebyar BCA di Jakarta.

Kombinasi K pada (6) yaitu frasa dalam acara gebyar BCA dan di Jakarta masing-masing adalah K acara dan tempat. Sebagai pembuktian didahulukan K acara daripada $\mathrm{K}$ tempat dapat dilihat dari teknik analisis berikut.

(6a) Ibu mendapatkan hadiah di Jakarta dalam acara gebyar BCA.

(6b) Ibu mendapatkan hadiah di Jakarta.

(6c) Ibu mendapatkan hadiah dalam acara gebyar BCA.

Pengubahan pola urutan K sebagai tambahan informasi pada (6a) secara gramatikal dan kemaknaan dapat diterima. Namun informasinya sedikit terputus karena susunan K yang ada seperti terdapat loncatan. Pengujiannya dapat dibandingkan pada data (6b) dan (10-c), kedua data yang salah satu K-nya lesap tersebut tampak bahwa K acara (6c) lebih informatif dengan topikalisasi Verbanya daripada K tempat (6b).

Relasi dasar V sebagai penguasa klausa berhubungan dengan $\mathrm{S}$ dan $\mathrm{O}$ (1), $\mathrm{O}$ berhubungan dengan $\mathrm{V}$ karena merupakan Vtrans yang ditandai dengan me-kan. Maka O bersifat pembatas dari klausa tersebut. Kemudian garis ke-2 merupakan hubungan directional antara inti klausa yaitu $\mathrm{V}-\mathrm{O}$ dengan $\mathrm{K}$ acara dan garis 3 juga dapat digunakan untuk menghubungkan $\mathrm{V}-\mathrm{O}$ dengan $\mathrm{K}$ tempat yang mana hanya berkepentingan sebagai informasi tambahan. Garis ke-4 merupakan klausa utuh yang diterangkan oleh kedua peran $\mathrm{K}$.

Dalam urutannya, $\mathrm{K}$ acara didahulukan daripada $\mathrm{K}$ tempat secara kuantitas jangkauan pemakaian yang kemudian diikuti dengan penambahan $\mathrm{K}$ waktu (jika perlu). Hal ini disebabkan bahwa $\mathrm{K}$ acara mempunyai relasi kejadian yang dekat dengan $\mathrm{V}$. 


\subsection{Lokatif - metodikal}

(7) Dinda bekerja dengan tekun di sebuah Bank swasta.

Data (7) K dengan tekun di sebuah Bank swasta menunjukkan informasi yang paralel dengan koherensi yang tinggi. Untuk menyelidiki kadar keparalelan informasinya dapat dilihat permutasi berikut.

(7-a) Dinda bekerja di sebuah Bank swasta dengan tekun.

Permutasi yang terjadi (7a) secara gramatikal dan semantisnya dapat berterima karena $\mathrm{V}$ bersifat netral tidak menuntut argumen yang pasti dari masing-masing pengisi. Namun jika K tempat didahulukan dari K cara, informasinya sedikit terputus. Seperti yang dikatakan oleh Geuder, Pittner, Adger and Tsoulas (2005) bahwa K cara yang disebut pula Adverbia memiliki ikatan batin dengan VP (verba predikat). VP yang dimaksud adalah $\mathrm{V}$ transitif atau intransitif yang hanya dapat berkorespodensi dengan Manner (K cara).

Untuk membuktikan hal tersebut, maka perlu adanya teknik analisis misalnya lesapnya prep pada kedua frasa prep menjadi Adv.

(7-b) Dinda bekerja tekun di sebuah Bank swasta.

(7-c) Dinda bekerja sebuah bank swasta dengan tekun

Perubahan dari (7-b) menunjukkan bahwa K cara tekun kadar keintian dengan prep rendah, dibandingkan $\mathrm{K}$ tempat yang berpreposisi di. Prep di wajib ada untuk menunjukkan $\mathrm{K}$ tempat yang dapat diletakkan di belakang $\mathrm{K}$ cara. Jika prep di dilesapkan maka (7-c) tidak lengkap. Berdasarkan bukti tersebut kadar penyusunan kombinasi secara seri antara $\mathrm{K}$ cara dengan $\mathrm{K}$ tempat itu dalam sebuah kalimat deklaratif adalah $\mathrm{K}$ cara didahulukan daripada $\mathrm{K}$ tempat.

\subsection{Lokatif - Instrumental (K tempat- $K$ alat)}

K yang bersifat instrumental sering dijumpai pada kalimat dengan Vtransitif.

(8) Ayah memotong kayu dengan gergaji di belakang rumah.

Data (8) jika urutan K tempat-alat yaitu Ayah memotong kayu di belakang rumah dengan gergaji, pada dasarnya memiliki pesan yang dapat dipahami. Namun terdapat informasi yang terputus atau meloncat. Hal ini disebabkan karena V-nya 
bermakna tindakan yang membutuhkan alat sebagai penjelasan informasi $\mathrm{V}$ yaitu $\mathrm{K}$ alat. Untuk dapat menentukan urutan yang signifikan dapat diterapkan dengan teknik balik.

(8a) Dengan gergaji ayah memotong kayu di belakang rumah.

(8b)*. Ayah dengan gergaji memotong kayu di belakang rumah.

(8c)? Di belakang rumah ayah memotong kayu dengan gergaji.

\subsection{Lokatif -Kausal (K tempat- K kausal)}

Kombinasi $\mathrm{K}$ tempat dan $\mathrm{K}$ kausal dapat digambarkan pada data berikut.

(9) Sedikitnya sebelas rumah dan toko rusak akibat gempa yang berkekuatan 6,8 skala ritcher (SR) di Yogyakarta.

(9a) Sedikitnya sebelas rumah dan toko rusak di Yogyakarta akibat gempa yang berkekuatan 6,8 skala ritcher (SR).

(9b) ? Di Yogyakarta akibat gempa yang berkekuatan 6,8 skala ritcher (SR) sedikitnya sebelas rumah dan toko rusak.

(9c) Akibat gempa yang berkekuatan 6,8 skala ritcher (SR) di Yogyakarta sedikitnya sebelas rumah dan toko rusak.

(9d)? Sedikitnya sebelas rumah dan toko Akibat gempa yang berkekuatan 6,8 skala ritcher (SR) di Yogyakarta rusak.

(9e) ?Sedikitnya sebelas rumah dan toko di Yogyakarta akibat gempa yang berkekuatan 6,8 skala ritcher (SR) rusak.

Tampaknya letak fungsi $\mathrm{K}$ yang bersifat fleksibel pada $\mathrm{K}$ tempat lebih tepat ditempatkan setelah $\mathrm{K}$ kausal. Pada dasarnya $\mathrm{K}$ dapat ditempatkan di manapun baik sebelum SP (9b dan 9c), diantara SP (9d dan 9e), dan setelah P (9 dan 9a). Pada data K kausal terlihat tidak bisa ditempatkan diantara S dan P. Maka dapat ditentukan jika pada kalimat terdapat 2 fungsi $\mathrm{K}$ yaitu kausal dan tempat, penyusunannya didahulukan $\mathrm{K}$ kausal kemudian $\mathrm{K}$ tempat.

\subsection{Temporal- Acara (K waktu- K acara)}

Kombinasi $\mathrm{K}$ yang melibatkan $\mathrm{K}$ waktu- acara dapat dicontohkan sebagai berikut.

(10) Letnan Jenderal Marciano Norman memeriksa barisan pasukan dalam acara serah terima jabatan Komandan Kondiklat TNI AD, Jumat (21/10).

(10a) Letnan Jenderal Marciano Norman memeriksa pasukan (pada) Jumat (21/10) dalam acara serah terima jabatan Komandan Kondiklat TNI AD. 
Data (10) K acara didahulukan letaknya di belakang PO kemudian disusul K waktu. Pada dasarnya kedua K tersebut dapat bergantian/ fleksibel posisi letaknya seperti pada (18a) atau dapat diletakkan di depan kalimat maupun sebelum P karena P bersifat netral. Karena kombinasi K acara-waktu tergolong dalam satu kelompok yang menunjukkan waktu. K acara dapat menunjukkan waktu secara abstrak dan $\mathrm{K}$ waktu menunjukkan kejelasan waktu. Namun peneliti menentukan jika letak $\mathrm{K}$ acara didahulukan terlebih dahulu daripada $\mathrm{K}$ waktu.

\subsection{Temporal-Metodikal ( $K$ waktu- $K$ cara)}

Kombinasi K waktu dan cara dapat dicontohkan sebagai berikut.

(11) KPK menggeledah ruang DPR dengan spontan pada Sabtu pagi.

Data (11) K cara didahulukan daripada K waktu. K waktu pada (11) bersifat lebih fleksibel dibandingkan dengan $\mathrm{K}$ cara pada FP dengan spontan. $\mathrm{K}$ cara lebih memiliki hubungan dengan verba menggeledah yang lebih membutuhkan $\mathrm{K}$ cara terlebih dahulu dan biasanya dapat ditentukan dengan $\mathrm{K}$ cara baik dengan frasa dengan spontan ataupun dengan frasa lain, misalnya dengan sengaja, dengan pemberitauan, $d s b$. Letak K cara dapat diletakkan di belakang V jika V transitif dan K waktu dapat menyusul di belakangnya. K waktu memiliki beberapa posisi yang lebih fleksibel daripada K cara.

\subsection{Temporal-Instrumental}

(12) Seorang biksu Tibet menyiram dirinya sendiri dengan bahan bakar pada Rabu (26/10).

Jika $\mathrm{K}$ alat digunakan dalam kalimat transitif lebih baik diletakkan setelah P/O. K alat mempunyai pergerakan yang tidak begitu bebas jika dibandingkan dengan $\mathrm{K}$ waktu. Karena K alat dapat ditentukan melalui verbanya. Seperti pada data (12) K alat didahulukan peletakkannya sebelum $\mathrm{K}$ waktu. $\mathrm{K}$ alat dengan bensin bakar merupakan keterangan dari Verba menyiram. Verba menyiram lebih membutuhkan $\mathrm{K}$ alat terlebih dahulu daripada $\mathrm{K}$ waktu. 


\subsection{Temporal-kausal}

(13) Sedikitnya sebelas rumah dan toko rusak akibat gempa yang berkekuatan 6,8 skala ritcher (SR) sekitar pukul 10.16 kemarin (13/10).

Data (13) kombinasi keduanya tampak fleksibel jika ditukar tempat. Namun K akibat secara semantis lebih dibutuhkan sebagai K Verba rusak. V rusak secara makna membutuhkan penyebab kerusakan yang teradi. Maka diikutkanlah penyebabnya. K waktu dalam kalimat ini bersifat fleksibel, jadi dapat ditempatkan setelah K sebab.

\section{Pembahasan}

Pola urutan fungsi $\mathrm{K}$ dalam hubungannya dengan predikat verba sangat dipengarui dari peran semantis verbanya. Dari bermacam-macam kombinasi yang ada, dapat dituliskan bahwa 1) $\mathrm{K}$ tempat dan waktu lebih bersifat fleksibel peletakannya yaitu dapat ditempatkan di manapun kecuali diantara PO. Hal ini menunjukkan bahwa fungsi $\mathrm{K}$ tempat dan waktu tidak memiliki ketegaran dalam penyusunan pola urutan karena $\mathrm{K}$ ini merupakan $\mathrm{K}$ secara umum. Namun, K tempat bersifat tegar jika V bersifat lokatif. 2) fungsi $\mathrm{K}$ alat, cara, dan penyerta dapat selalu berada di belakang $\mathrm{P}$, karena fungsi $\mathrm{K}$ ini bersifat tegar dengan $\mathrm{V}$ yang ada khususnya verba transitif dengan $\mathrm{V}$ tindakan untuk fungsi $\mathrm{K}$ alat, $\mathrm{V}$ aksi untuk fungsi $\mathrm{K}$ cara. 3) Fungsi $\mathrm{K}$ penerima dapat ditemukan pada verba me-kan. 4) Fungsi K pelaku dapat ditemukan pada verba pasif. 5) Fungsi $\mathrm{K}$ tujuan dan sebab akibat tidak bergantung pada $\mathrm{V}$, kedua fungsi ini letaknya bebas seperti K tempat dan waktu pada verba yang tida berperan lokatif.

Berdasarkan keterangan tersebut maka dapat dibuat skema pola urutan yang dapat mengikat $\mathrm{P}$ verba transitif dan intransitif yang berperan 'tindakan/perbuatan, proses, dan instrmental' informasi yang disampaikan lebih jelas.

metodikal $>$ instrument $>$ Komitatif $>$ agen $>$ benefaktif $>$ final/goal $>$ kausal $>$ acara $>$ lokatif> temporal.

Skema tersebut berarti $\mathrm{K}$ yang berada di kiri mempuyai korelasi paling dekat dengan verba dan dapat ditulis di belakang $\mathrm{P} / \mathrm{PO} / \mathrm{Pl}$. Kemudian peran semakin ke kanan, $\mathrm{K}$ tersebut bersifat lebih fleksibel penulisan letaknya. Namun jika $\mathrm{P}$ verba berperan lokatif Maka $\mathrm{K}$ tempat korelasinya dengan $\mathrm{P}$ lebih tegar dituliskan langsung di belakang P/PO/PL. 


\section{SIMPULAN}

Berdasarkan temuan penelitian dan pembahasan simpulan yang dapat diambil adalah 1. penentuan pola urutan fungsi $\mathrm{K}$ dalam kalimat sangat bergantung dengan verba P. Peran P sangat menentukan fungsi K yang akan mengikutinya. Namun secara umum dapat dituliskan jika $\mathrm{K}$ waktu dan tempat bersifat fleksibel dapat ditempatkan di akhir kalimat jika P yang ada bukanlah Verba lokatif. Adapun fungsi K cara, alat, dan penyerta merupakan fungsi $\mathrm{K}$ yang mempunyai ikatan batin dengan $\mathrm{V}$ karena keberadaannya terikat dengan V. 2. Terdapat perubahan makna jika dimodifikasi bentuk fungsi K khususnya penggantian preposisi. 3. Terdapat keajegan preposisi pada fungsi $\mathrm{K}$ yang mengikuti verba lokatif seperti $\mathrm{V}$ tiba yang tegar diikuti fungsi $\mathrm{K}$ tempat dengan preposisi $d i-$.

\section{DAFTAR PUSTAKA}

Aarts, B. (1997). English syntax and argumentation. Houndmills: Macmillan Press, Ltd.

Adger, D., \& George Tsoulas. (2004). Circumstantial Adverbs and Aspect. dalam Jennifer R. Austin, Stefan Engelberg and Gisa Rauh. (edt). Adverbials the Interplay Between Meaning, Context, and Syntactic Structure. Philadelphia. John Benjamins North America Publishing.

Austin, R. J., \& Stefan Engelberg, Gisa Rauh. (2004). Current issues in the syntax and semantics of adverbials dalam Jennifer R. Austin, Stefan Engelberg and Gisa Rauh. (edt). Jurnal Adverbials the Interplay Between Meaning, Context, and Syntactic Structure. Philadelphia. John Benjamins North America Publishing.

Chaer, A. (2009). Sintaksis bahasa Indonesia (pendekatan proses). Jakarta: Rineka Cipta.

Parera, J.D. (2009). Dasar-dasar analisis sintaksis. Jakarta: Erlangga.

Pittner, K. (2004). Where syntax and semantics meet: adverbial positions in the German middle field. dalam Jennifer R. Austin, Stefan Engelberg and Gisa Rauh. (edt). Jurnal Linguistik Aktuell/Linguistics Today (LA) berjudul Adverbials the Interplay Between Meaning, Context, and Syntactic Structure volume 70. Philadelphia. John Benjamins North America Publishing. Hal 253-287.

Ramlan, M. (2001). Sintaksis (cetakan ke delapan). Yogyakarta: CV. Karyono.

Subroto, E. (2007). Pengantar metode penelitian linguistik struktural. Surakarta: LPP UNS, dan UPT Penerbitan dan Percetakan UNS. 
Sudaryanto. (1979). Predikat-objek dalam Bahasa Indonesia keselarasan pola urutan. Yogyakarta: Djambatan.

Sudaryanto. (1988). Metode penelitian linguistik bagian pertama: ke arah memahami metode linguistik. Yogyakarta: Gadjah Mada University Press.

Sudaryanto. (1988). Metode linguistik bagian kedua: metode dan aneka teknik pengumpulan data. Yogyakarta: Gadjah Mada University Press.

Sudaryanto. (1993). Metode dan aneka teknik analisis bahasa: pengantar penelitian wahana kebudayaan secara linguistik. Yogyakarta: Duta Wacana University Press.

Sukesti, R. Verba Berpelengkap dalam bahasa Indonesia. dalam MLI Volume 20. No.1 (Maret 2002), hal.21-34.

Sutopo, H.B. (2006). Metodologi penelitian kualitatif: dasar teori dan terapannya dalam penelitian. Surakarta: Universitas Sebelas Maret.

Schweikert, W. (2005). The Order of Pps in German - Empirical Observations. Dalam Werner Abraham and Elly van Gelderen.(edt). Jurnal Linguistik Aktuell/Linguistics Today (LA) berjudul The Order of Prepositional Phrases in the Structure of the Clause volume 83. Amsterdam/Philadelphia: John Benjamins Publishing Company. Hal 47-132.

Verhaar, J.W.M. (2001). Asas-asas linguistik umum. Yogyakarta: Gadjah Mada University Press. 